\title{
Trace Metals Related to Historical Iron Smelting at Hopewell Furnace National Historic Site, Berks and Chester Counties, Pennsylvania
}

Iron ore containing elevated concentrations of toxic trace metals was smelted at Hopewell Furnace during its 113 years of operation. Iron ore, cast iron furnace products, slag, soil, groundwater, streamwater, and streambed sediment were sampled to determine the distribution and concentrations of trace metals released into the environment during historical iron-smelting operations. In addition, benthic-macroinvertebrate samples were collected, and habitat surveys were completed at five stream sites to assess possible effects of past smelting operations on aquatic life. Toxic metals were not present at concentrations of concern in water, soil, or stream sediments, despite being elevated in ore, slag, and cast iron furnace products.

\section{Introduction}

Iron ore containing elevated concentrations of trace metals was smelted at Hopewell Furnace during its 113 years of operation (1771-1883). The ore used at Hopewell Furnace was obtained from iron mines within 5 miles of the furnace. The iron-ore deposits were formed about 200 million years ago and contain abundant magnetite, the primary iron mineral, and accessory minerals enriched in arsenic, cobalt, copper, lead, and other metals.

Hopewell Furnace (fig. 1), built by Mark Bird during 177071, was one of the last of the charcoal-burning, cold-blast iron furnaces operated in Pennsylvania. The most productive years for Hopewell Furnace were from 1830 to 1837 . Castings were the most profitable product, especially the popular Hopewell Stove. More than 80,000 stoves were cast at Hopewell, which produced as many as 23 types and sizes of cooking and heating stoves. Beginning in the 1840 s, the iron industry shifted to large-scale, steam-driven

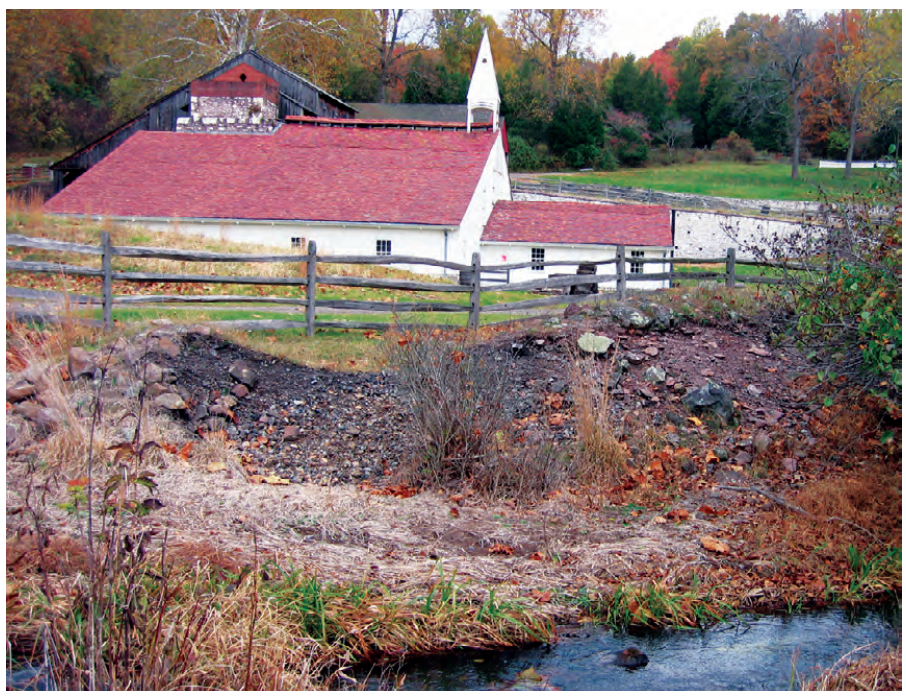

Figure 1. The cast house at Hopewell Furnace National Historic Site, Pennsylvania. The cast house encloses the furnace. The stone stack of the furnace is visible on the left side of the cast house. In the foreground, part of the furnace slag pile is exposed and makes up the left bank of French Creek. coke and anthracite furnaces. Independent rural enterprises like Hopewell could no longer compete when the iron and steel industries consolidated in urban manufacturing centers. The furnace ceased operation in 1883 (Kurjack, 1954).

The U.S. Geological Survey (USGS), in cooperation with the National Park Service, completed a study at Hopewell Furnace National Historic Site (NHS) in Berks and Chester Counties, Pennsylvania, to determine the fate of toxic trace metals, such as arsenic, cobalt, and lead, released into the environment during historical iron-smelting operations. The results of the study, conducted during 2008-10, are presented in this fact sheet.

\section{What Was Sampled}

Iron ore, slag, soil, groundwater, streamwater, streambed sediment, and benthic macroinvertebrates were sampled at and near Hopewell Furnace during 2008-10 (fig. 2) and analyzed using standard techniques. Cast iron furnace products in the Hopewell museum were analyzed in partnership with West Chester University using a portable X-ray fluorescence spectrometer, which allowed on-site, nondestructive, real-time analysis. Complete analytical results and details of the USGS study at Hopewell are presented in the technical report by Sloto and Reif (2011).

\section{Results of Sampling}

Iron-ore samples from two of the mines that supplied ore to Hopewell Furnace were analyzed for trace metals. Most of the ore samples contained concentrations of arsenic, cobalt, copper, iron, lead, manganese, nickel, vanadium, and zinc that are typical of local iron ore but higher than the average concentrations found in most rocks.

Slag, a glass-like waste material produced during the ironsmelting process, was discarded near the furnace. Laboratory analyses of samples from three slag piles near the furnace showed manganese, iron, nickel, and zinc were concentrated in slag.

Soil was sampled at eight locations. Seven sites were near the furnace, and one site about 0.6 mile away from the furnace was sampled for comparison (background conditions). The soil near the furnace had elevated concentrations of chromium, copper, iron, lead, and zinc compared to the background soil samples. However, the concentrations of trace metals met Pennsylvania Department of Environmental Protection standards for non-residential use. 
Ten cast iron artifacts on display in the Hopewell Furnace visitor center museum, including eight stoves, a footed pot, and a kettle, were analyzed for trace-metal content. Results of the analyses indicate that arsenic, chromium, copper, lead, and zinc were incorporated into the cast iron through the smelting process during production at Hopewell Furnace.

Hopewell Furnace NHS uses groundwater to supply drinking water to park visitors and employees. A groundwater sample collected from the park well for field and laboratory analysis met all applicable U.S. Environmental Protection Agency drinking-water standards.

Five stream sites were sampled during fall low-flow conditions. Four sites were on French Creek, and one background site was on Baptism Creek (fig. 2). Streamwater, streambed sediment, and macroinvertebrates were sampled, and a habitat evaluation was conducted at each site. Results of chemical analyses of the streamwater indicated good overall water quality. The background site on Baptism Creek generally had the lowest concentrations of constituents. Concentrations of metals in the streamwater samples met U.S. Environmental Protection Agency criteria for protection of aquatic organisms.

Streambed-sediment sampling results indicated higher concentrations of all metals, except nickel, at sites on French Creek than at the background site on Baptism Creek. Concentrations of aluminum, cadmium, and nickel were highest in sediment at the most upstream site on French Creek and generally decreased in concentration downstream, indicating that the source of these metals is upstream from Hopewell Furnace and that the metals are possibly related to discharge from Hopewell Lake. The highest concentrations of arsenic, boron, cobalt, copper, iron, lead, manganese, mercury, and zinc were measured in sediment at sites on French Creek below Hopewell Furnace, indicating that the source of these metals may be related to Hopewell Furnace operations. Concentrations of metals, except copper, in sediment at the five stream sites met guideline concentrations for protection of aquatic organisms. The concentration of copper at one site exceeded the guideline concentrations.

Sampling of benthic macroinvertebrates (bottom-dwelling organisms, such as insect larvae, worms, and clams) showed that all four sites sampled on French Creek had disturbed communities and degraded stream conditions for aquatic life when compared to the background site on Baptism Creek. Habitat evaluations were performed to assess the surrounding physical habitat that affects the condition of the benthic-macroinvertebrate community. Habitat conditions at the background site on Baptism Creek and the upstream site on French Creek were good, but degraded conditions were found at downstream sites on French Creek that appear to be related to a lack of stable substrate, erosion, and deposition.

\section{Summary and Conclusions}

A study was done by the U.S. Geological Survey, in cooperation with the National Park Service, to determine the distribution and concentrations of trace metals in Hopewell Furnace NHS related to historical iron-smelting operations. Iron ore, slag, cast iron furnace products, soil, groundwater, streamwater, and streambed sediment were sampled and analyzed for trace-element concentrations. In addition, benthic macroinvertebrates were analyzed in samples from the five stream sites where the streamflow and streambed-sediment samples were collected.

Some trace metals were present in elevated concentrations in the iron ore smelted at Hopewell. Arsenic, chromium, copper, lead, and zinc were incorporated into the cast iron produced by Hopewell Furnace. Manganese was concentrated in slag along

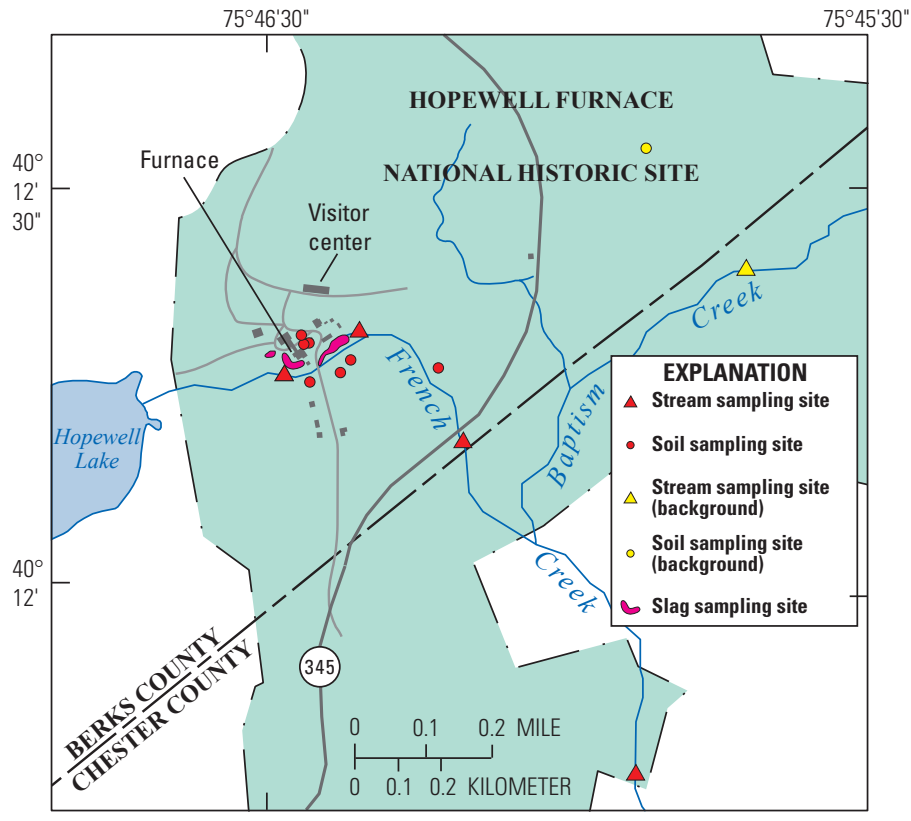

Figure 2. Locations of slag, soil, and stream sampling sites in Hopewell Furnace National Historical Site, Pennsylvania.

with iron, nickel, and zinc. The soil near the furnace had elevated concentrations of chromium, copper, iron, lead, and zinc compared to background soil concentrations.

Arsenic, cobalt, lead, and other toxic metals, which could pose a significant health risk to visitors and park employees, were not released to soil, slag, groundwater, or streamwater. Soil samples collected from the Hopewell Furnace NHS met Pennsylvania Department of Environmental Protection standards for non-residential use. Groundwater samples from the park supply well met U.S. Environmental Protection Agency drinking-water standards. Concentrations of metals in streamwater at the five stream sampling sites met criteria for protection of aquatic organisms. Concentrations of metals in sediment from the five stream sampling sites met guidelines for the protection of aquatic organisms, with the exception of copper at one site.

—Ronald A. Sloto

\section{References Cited}

Kurjack, D.C., 1954, Hopewell Village National Historic Site Pennsylvania (now Hopewell Furnace): National Park Service Historical Handbook Series No. 8, accessed on February 25, 2011, at http://www.nps.gov/history/history/online_books/hh/8/ hh8toc.htm.

Sloto, R.A., and Reif, A.G., 2011, Distribution of trace metals at Hopewell Furnace National Historic Site, Berks and Chester Counties, Pennsylvania: U.S. Geological Survey Scientific Investigations Report 2011-5014, 79 p.

For additional information, contact:

Director, U.S. Geological Survey Pennsylvania Water Science Center 215 Limekiln Road New Cumberland, PA 17070

http://pa.water.usgs.gov 